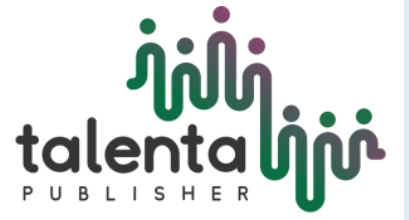

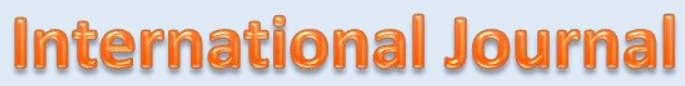
of Ecephysiology

\title{
Photoreceptors Diversity of Fishes Eyes: (A Review)
}

\author{
Abdul Razak ${ }^{1}$ \\ ${ }^{1}$ Department of Biology FMIPA, Padang State University Jl. Prof. Dr. Hamka, Air Tawar Campus \\ Padang, 25131, West Sumatra, Indonesia.
}

\begin{abstract}
This article is a review about the diversity of photoreceptors in various fishes. In this article, the author discusses the photoreceptors of freshwater fish, reef fish, sharks and tuna, and deep sea fish. The purpose of this article are to provides illustration and explanations about the diversity of photoreceptor of fish eye and its relationship with the ecosystem. The information is important in the development of fishery technology.
\end{abstract}

Keywords: diversity, photoreceptors, and fishes

Received 1 July 2019|Revised 20 August 2019| Accepted 31 August 2019

\section{Introduction}

Light is an important ecological factor for fish. Fish habitat in water, both freshwater, and saltwater (sea) is a determining factor for fish to be able to live and maintain sustainability for their offspring. Fish are vertebrate animals that are able to live in diverese place, from the Himalayas with an altitude of 8000 meters from sea level to the Mariana Trench in the Pacific Ocean with a depth of 10,000 meters. We find fish living with a variety of habitats as evidence that fish are adaptive organisms and able to utilize light effectively.

The ability of fish to use light is supported by the adaptation of fish eyes that are very adaptive to the environment of their living habitat. Adaptation is the interaction of fish with the environmental factors of the habitat where the fish lives.

Fish life is strongly influenced by the ecological adaptation of the eye as the organ of vision. The important forms of ecological adaptation between freshwater and saltwater (sea) aquatic environments and fish eyes are found in fish eye photoreceptors. Photoreceptors are part of the retina that is capable of capturing light energy in the form of photons originating from light entering the sea water (Razak et al., 2005).

\footnotetext{
*Corresponding author at: Biology Study Program, Faculty of Science and Technology, Jambi University. Jambi, Indonesia.

E-mail address: ar210371@fmipa.unp.ac.id 
According to Maxwell's theory, light is distributed in the form of electromagnetic waves with a speed of about 300 thousand kilometers per second. Wavelength with a range between 7,800-3,600 $\mathrm{A}^{0}$ (Armstrong; 1 Armstrong $=1 \times 10^{-10}$ meters) with a frequency ranging from 3.87 $\mathrm{x} 10^{14} \mathrm{x}-8.35 \times 10^{14}$. Naturally, the light will determine the contrast of the surrounding environment. The number of particles of light will determine the light fading coefficient The unit of light called photons in dimensions of $\mathrm{cm}^{2} /$ second. Photons (units of light) which are also the energy that are utilized in the process of animal vision, photosynthesis, phototropism and so on. Reverse photons are determined by three quanta in contact with momentum, energy, and polarization. (Zajonc, 2003). This is related to the amount of light reflected on the surface of the water which affects the amount of light entering the water column. Furthermore, according to Nybakken (1988) the penetration of light entering sea water is influenced by the absorption of light, water particles, wavelengths of light, water brightness, the reflection of light by water, and the position of latitude and season. On rivers, the penetration of light is influenced by currents and tides. Tides affect turbidity of water. If the water is cloudy, the intensity of light entering the river water column is low. If the tides and currents are weak, the water is clear and this increases the intensity of light entering the river water column (Lionardi et al., 2005; Malone and Neale, 1981).

This review article describes the relation of light conditions in river ecosystems, coral reef ecosystems, neritic ecosystems (water column to a depth of 200 meters) and deep seas above $200 \mathrm{~m}$ (Douglas, Partridgeb and Marshalls, 1998) at sea level to diversity of photoreceptor structure of river fish, reef fish, pelagic fish and deep sea fish. Information like this is still not revealed so much that it becomes important in understanding the adaptation of fish eye to their habitat which is affected by light.

\section{Discussion}

\subsection{Diversity of Photoreceptors}

Figure 1 shows three types of cone cells or photoreceptors, single cone, double cone, and twin cone. These three types of cone cells are found in fish that live in rivers, estuaries, coral reefs in a column of seawater or pelagic fish. Recent discoveries found different type are in deep-sea fish where rod cells act as photoreceptors (https://www.sciencealert.com/deep-sea-).

When we compare figure 2,3, and 4, the shape of the mosaic photoreceptors of reef fish, pelagic fish, and different sharks can be seen. The difference is caused by differences in the penetration of light entering the sea water. In sharks, or cucut fish, another unique comparison is the cucut fish develops the ability of vision by use a limited light from the environment. This is due to the photoreceptors that rely on are rod cells and have pigments. The rod cells are short and some are long. Long rod cells can use very weak light very well. Lemon cucut has rod cells 
that are longer than rod cells in white cucut fish. This illustrates that lemon cucut fish is very well adapted to its habitat environment. Cucut fish develops the ability of vision that is able to utilize a little light from the environment. This is due to the photoreceptors that they rely on are rod cells and have pigments. This has the same adaptation with deep-sea fish that is able to take advantage of minimal light in their habitat (Razak, 2017).

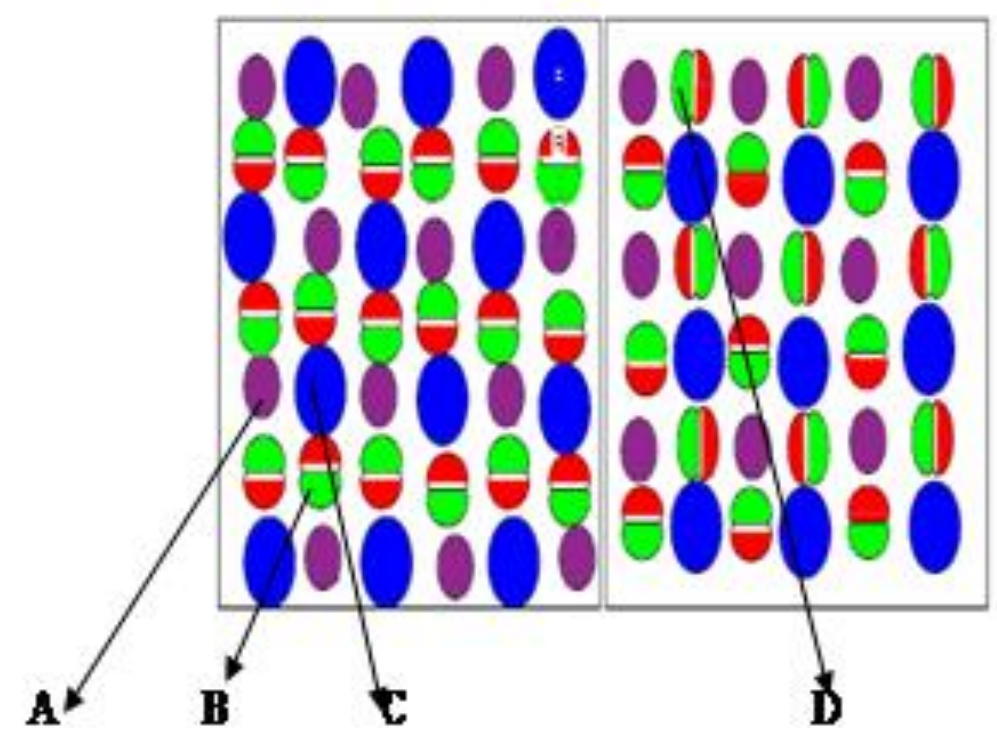

Figure 1. Photoreceptor mozaic. A. Single cone cell; B. Rod cell; C. Double cone cell; D. Twin cone cell (Harder, 1975 in Razak, 2017).

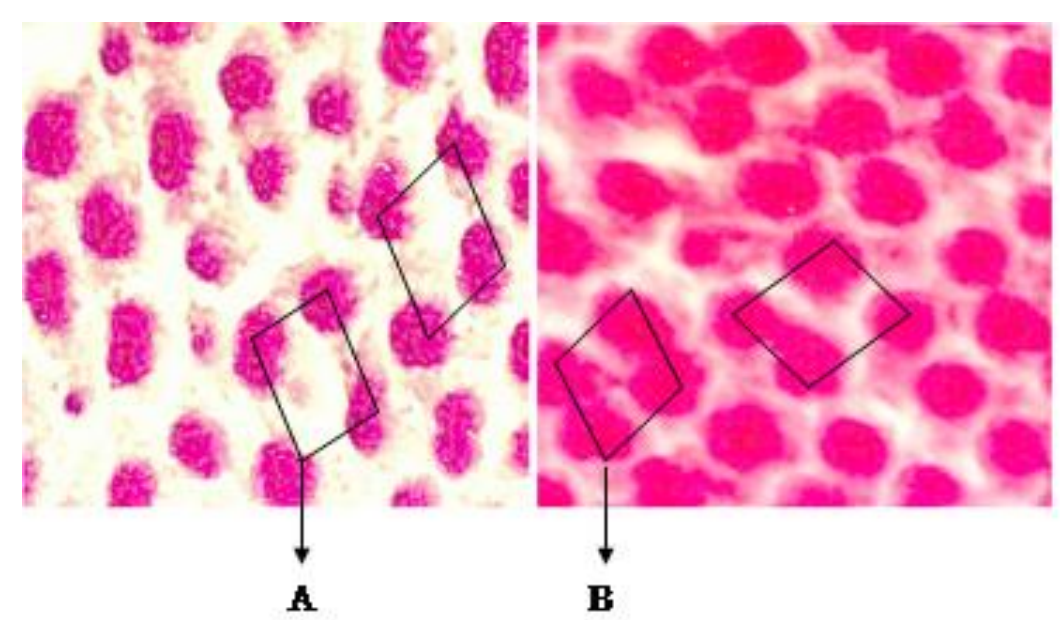

Figure 2. Square mozaic of cone cell. A. Kepe Kalong Fish (C. Collare); B. Kepe-Kepe Gajah Fish (C. Lunula). (Razak, 2017). 


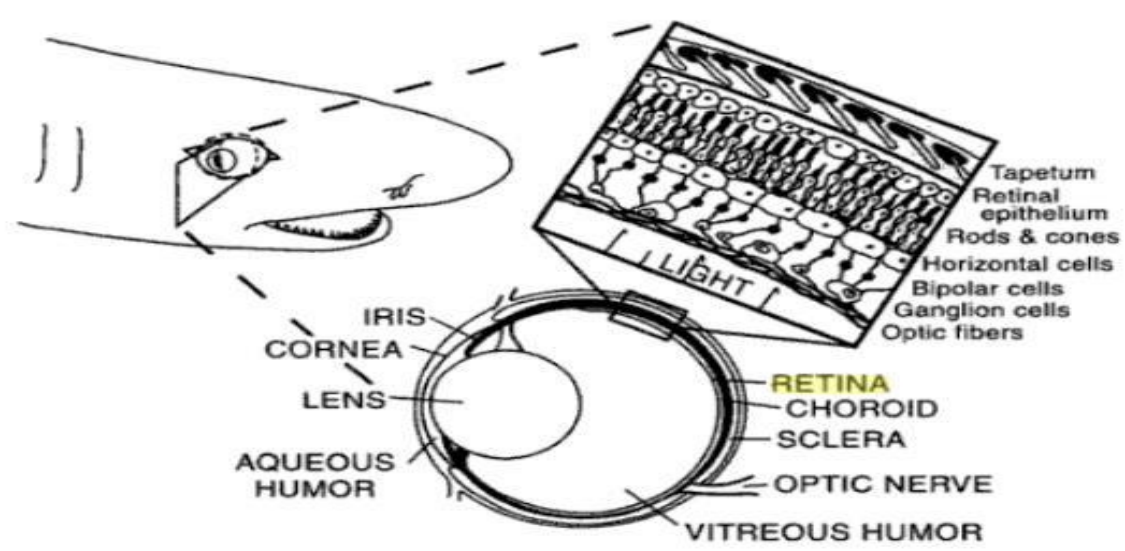

Figure 3: Shark Sensors and Sensory Organs (Heuter and Gilbertt, 1990)

Likewise in the case of rivers, the penetration of light affected by currents and tides. Usually the more upstream is clearer except on rainy days. River conditions are very relative but light penetration can penetrate the bottom of the water and is influenced by the size of the river.

\subsection{The diversity of Photoreceptor Density and the Vision Axes of Eye}

In addition to the shape or structure of different photoreceptors, the photoreceptor density differs according to the position or area of the retina. There are ventral, dorsal, temporal, and nasal area of retina. The diversity of density based on the position or area mentioned above, in the retina, is also found in the family of Kepe-kepe fish that live on coral reef ecosystems. Photoreceptor density in the eyes of Kepe-kepe fish (Chaetodontidae) in the ventral, dorsal, temporal, and nasal parts also varies as found in figure 1. (Razak, 2005). The picture above shows that the densest photoreceptor density in the nasal portion ranges from $4000-4500 \mathrm{~mm}^{2}$. In the ventral area the density reaches $1000-3000 \mathrm{~mm}^{2}$. There are types of photoreceptors that are single cone cell types and there are also double cone cells. This shows that the orientation of the sight of Tilapia spp is straight towards the front. This has the same orientation with Kepekepe fish. 


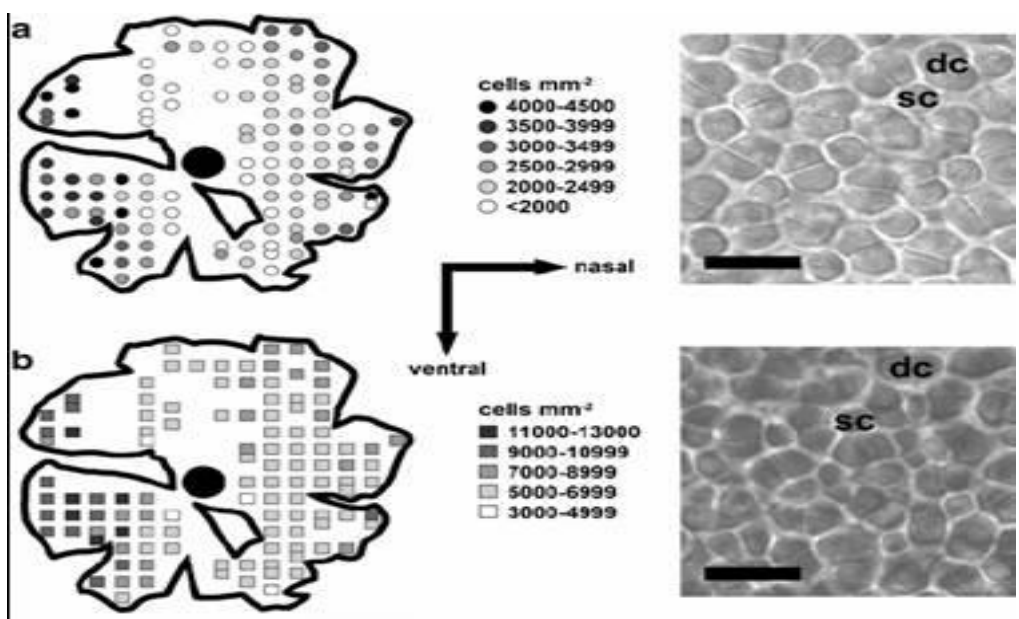

Figure 4. Photoreceptor cell density in tilapia (Tilapia spp)

(https://www.google.com/search?q=cone+cell+Tilapia\&dcr).

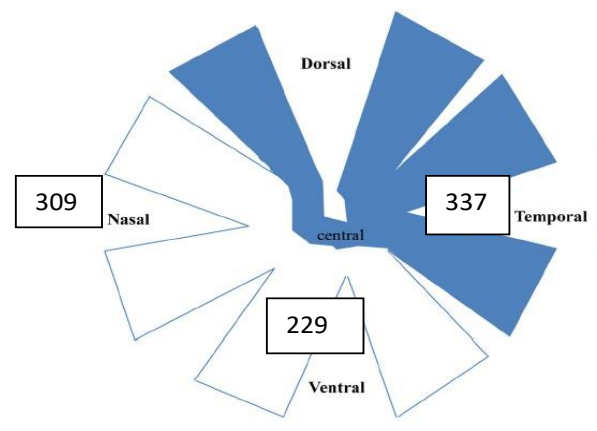

Chaetodon falkula (Ikan Karang) (0.012mm2) Pelagis

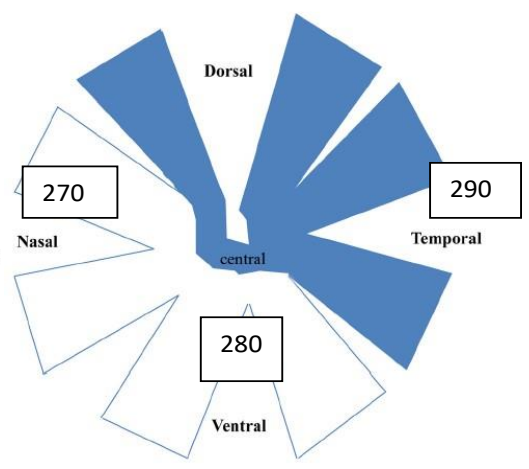

Bluefin Tuna (Thunnus spp)(Ikan

Figure 5. Variation of ventral, nasal, dorsal and temporal density from the types of Kepe-kepe and Tuna fish.

This affects the orientation of vision. Based on the highest density mentioned above, it can be determined the orientation or visual axis of Kepe-kepe fish which is straightforward. Accarding to Tamura (1957) the axis of vision is determined by the highest cone cell density. Furthermore, Blaxter (1980) describes the axis of vision (visual axis) identified to find out the habits of fish seeing objects or seeing food. This is important in the application of environmentally friendly fishing technology.

\subsection{The relationship between Photoreceptor Diversity and Ecosystems}

Table 2 describes the relationship between habitat conditions (ecosystems) to photoreceptor forms and color vision. This data shows that starting from the surface of the water surface to penetrate towards the bottom of the water, light fading occurs. This fading affects the amount of 
light entering. The amount of light entering in the form of wavelengths affects the number of types of photoreceptors, their shape or pattern of mosaics, their density and the axis of vision or the main orientation of vision in looking for food. Besides that, the conditions above affect the ability to see the color spectrum which is the result of reflecting light by water.

After the above is described photoreceptor diversity of shape, pattern, density, axis and ability to see colors that are closely related to penetration according to a depth ranging from rivers, coral reefs, open sea with a depth of more than $100 \mathrm{~m}$ and deep sea more than $200 \mathrm{~m}$. Table 3 describes ecosystem relationships, species of fish, photoreceptor mosaic patterns and sensitivity to light waves.

Table 2. Ecosystem relations to photoreceptor forms and color vision (various sources)

\section{No. Variety of Ecosystems, Forms of Photoreceptor Color that can be seen Species, or Genus of Fish Cells}

1. Tropical River Fish

2. Sub tropical River Fish

3. Coral Fish

4. Sharks (Neritic Zone)

5. Tuna (Thunnus spp)

6. Deep Sea Fish
Single and Twin

Single and Double

Single, Double, Twin

Green, Blue, Yellow,

UV

and Red

Blue, Green

Single and Rod cells

Black and White

Single, Double, Twin

Green, Blue, Red

Rod like cone

Bioluminescens

Tables 2 and 3 show that photoreceptor coral reefs are patterned like mosaics and some are not patterned. Furthermore, in the pelagic fish eye, mosaic patterned photoreceptors vary as shown in Figure 3. This means that the sight of pelagic fish is very good. Cucut or shark has a similar strategy in regulating the use of rod cells as light catchers, because both habitats are generally at depths of 100-200 m or more that have similarities with deep-sea fish, which have rod cells like cone cells as a strategy for capturing minimal light. Furthermore, light sensitivity is a function and adaptation to the environment. The ability to use light and use it even in minimal conditions is an advantage of the adaptation of fish that live in deep sea waters. This 
gives a meaning that the fish is able to use light to a minimum. Even if there is no light, the fish adapt without using the eyes, but instead use other sensor organs, namely the antenna or taste organs such as Satan sp (blindcat) from Mexico.

Table 3. Ecosystem relations, photoreceptor mosaic patterns, and eye sensitivity

\begin{tabular}{|c|c|c|c|c|}
\hline No. & Ecosystem & Fish Species or Genus & $\begin{array}{l}\text { Photoreceptor } \\
\text { Mozaic Pattern }\end{array}$ & $\begin{array}{l}\text { Sensitivity } \\
(\mathbf{n m})\end{array}$ \\
\hline 1. & $\begin{array}{ll}\text { Sub } & \text { Tropical } \\
\text { River } & \end{array}$ & $\begin{array}{l}\text { Archerfish (Toxotes } \\
\text { chatareus) }\end{array}$ & Patterned & $500-620$ \\
\hline 2. & Tropical River & Tilapia spp & Patterned & 550 \\
\hline 3. & Coral Reef & Kepe-kepe fish & $\begin{array}{l}\text { Not directed, } \\
\text { patterned with a } \\
\text { full range }\end{array}$ & $365 / 415-416$ \\
\hline 4. & $\begin{array}{l}\text { Water Column } \\
\text { (Neritic, } 200 \mathrm{~m} \text { ) }\end{array}$ & Tuna (Thunnus spp) & $\begin{array}{l}\text { Patterned } \\
\text { directional mosaic }\end{array}$ & $458-492$ \\
\hline 5. & $\begin{array}{l}\text { Deep } \\
<400 \mathrm{~m}\end{array}$ & Anoplogaster sp & $\begin{array}{l}\text { "rod-like cones," } \\
\text { not patterned }\end{array}$ & $468-494 \mathrm{~nm}$ \\
\hline 6. & Cave & Satan sp (blindcat) & Without eyes & 0 \\
\hline
\end{tabular}

is of $365 / 415-416$

\section{Conclusion}

The description above has revealed that the photoreceptor diversity of fish eyes is a form of adaptation to the amount of light entering the water column. The deeper the light, the role of cone photoreceptors is just as important. In fish that live with abundant light photoresptor plays a role in the form of patterns, density and concentration that support living activities in their habitat. Seballiknya in habitats with minimal light, the stem cell acts as an effective light reflector to support life activities. 


\section{Acknowledgments}

The author conveyed to the Chancellor of UNP, Dean of FMIPA UNP and Director of the UNP Postgraduate who had given permission and support to take part in the USU ICST Semirata 2018 in Medan.

\section{References}

[1] Blaxter, JHS (1980) Vision and the feeding of fishes. In: Bardach JE. Magnuson JJ, May RC. Reinhart JM (eds) Fish behavior and its use in the capture and culture of fishes. Proceedings of the conference on the physiological and behavioral manipulation of food fish as production and management tools. Int Center for Living and Aquatic Resources Management, Manila, p 32-1980.

[2] Heuter, R.E and Gilbertt, P.W. 1990. The Sensory world of Sharka, Discovering Shark American Littoral Society Highland, N.

[3] Nybakken, J.W. 1988 . Biologi Laut, Suatu Pendekatan Ekologi, Terjemahan, Eidman, M, Koesbiono dan D.G.Bengen. PT.Gramedia Jakarta

[4] Razak, A, Mulyonom S.B. dan Kaspul, A .,2005. Fisologi Mata Ikan, Penerbit Depatemen Pemanfaatan Sumberdaya Perikanan IPB.Bogor.

[5] Razak, A. 2017. Fotoreseptor Mata Ikan Laut, Penerbit Tausia, Jakarta (https://www.sciencealert.com/deep-sea-pearlside-fish-new-eye-cells-twilight, Jam 11, 28 Februari 2018). (https://www.google.co.id/search?q=cone+cell+Tilapia\&dcr) Jam 11.30, 28 Februari 2018).

[6] Tamura, T 1957. A study visual perception in fish. Especially resolving power and accomodation. Bulletin of Japanese Society of Scietific Fisheries. Fisheries Institute, Faculty of Agriculture .XII (9) 536-557. The organization of the retina and visual system, 1995 Editors: Helga Kolb, Eduardo Fernandez, and Ralph Nelson. Salt Lake City (UT): University of Utah Health Sciences Center United States .

[7] Zajonc, A. 2003 Light reconsidered, Optical Society of America. 